\title{
Analisis Harmonisa pada Sistem AC Microgrid Terhubung ke Grid
}

\author{
Zulmiftah Huda ${ }^{1}$, Nining Purwasih ${ }^{2}$, Diah Permata ${ }^{3}$, Dikpride Despa ${ }^{4}$ \\ Jurusan Teknik Elektro Universitas Lampung, Bandar Lampung \\ J1. Prof. Sumantri Brojonegoro No.1 Bandar Lampung 35145 \\ ${ }^{1}$ zulmiftah.huda@eng.unila.ac.id \\ 2nining.purwasih@eng.unila.ac.id \\ 3 diah.permata@eng.unila.ac.id \\ ${ }^{4}$ dikpride.despa@eng.unila.ac.id
}

Intisari - Kualitas daya telah menjadi faktor penting dalam layanan kelistrikan. Peningkatan pembangkitan tersebar atau dikenal dengan istilah distributed generation (DG), yaitu pembangkitan daya yang tersebar di seluruh sistem tenaga seperti pembangkit listrik tenaga matahari dan pembangkit listrik tenaga angin. Pada makalah ini penulis akan mengevaluasi dampak sumber energi terbarukan ini terhadap kualitas daya listrik pada skala sistem microgrid. Distorsi harmonisa yang timbul disebabkan konverter yang digunakan dalam mengkonversi Daya AC menjadi DC atau sebaliknya. Dari hasil analisis dapat dilihat harmonisa yang ditimbulkan dari konverter 12 pulsa terdapat harmonisa $11^{\text {th }}, 1^{\text {th }}$ dan $23^{\text {th }}$. Dengan menggunakan C-Type High-Pass filter, high-pass filter dan double-tuned filter. Dari hasil simulasi THD tegangan pada bus 1 adalah $17,03 \%$ setelah menggunakan filter harmonisa THD tegangan pada bus 1 menjadi $0,69 \%$. Dari hasil simulasi THD arus pada bus 1 yaitu $7,4 \%$ setelah dipasang filter harmonisa menjadi $0,48 \%$. Nilai THD setelah pemasangan filter 0,69 \% untuk tegangan dan dimana nilai THDv tersebut lebih baik dari sebelum pemasangan filter dan sudah memenuhi standar IEEE 519-1992 sebesar $\leq 5 \%$.

Kata kunci - Harmonisa, VSC, filter harmonisa.

Abstract - Power quality has become an important factor in electrical services. Increased small scale power generation or known as distributed generation (DG), the generation of power system, such as solar power generation and wind power generation. In this paper will investigate the impact of this renewable energy source on the quality of electric power for microgrid system scale. Harmonic distortion that occurs is due to the converter used to convert AC to DC power or DC to AC power. The results, it can be seen that the harmonics generated from 12 pulse converter are 11th, 13th and 23th. By using the C-Type High-Pass filter, high-pass filter and double-tuned filter. From the simulation results that THD voltage on bus 1 is $17.03 \%$ after using a harmonic filter THD voltage on bus 1 becomes $0.69 \%$. From the simulation results, THDi on bus 1 is $\mathbf{7 . 4 \%}$, after installing harmonic filter to THDi is $\mathbf{0 . 4 8 \%}$ and THDv value after installing the filter is 0.69\%. THDv value was eliminated by harmonics filter and appropriate with the IEEE 519-1992 standard $\leq$ $5 \%$.

Keywords- Harmonics, VSC, Harmonic filter.

\section{PENDAHULUAN}

Pembangkitan tenaga listrik yang handal dan berkualitas jika pembangkit berada sedekat mungkin dengan beban, pembangkit listrik tersebar (distributed generation) mengubah paradigma dalam sistem tenaga listrik. Sumber pembangkit terbarukan seperti sel surya, turbin angin dan sumber energi terbarukan lainnya memungkin berada dekat dengan beban. Berbagai sumber pembangkit berskala kecil ini memungkinkan untuk terhubung dengan jaringan tenaga listrik melalui konverter, yang mana ini dikenal dengan sistem microgrid [1]. Keunggulan dari sistem microgrid dapat beroperasi dalam dua kondisi yaitu terhubung dengan jaringan (grid connected) dan beroperasi tanpa terhubung dengan jaringan (islanding) [2].

Meskipun banyak keuntungan dan keunggulan dari sistem microgrid, ada beberapa permasalahan yang bisa saja muncul pada sistem microgrid seperti koordinasi sistem proteksi, regulasi tegangan dan kualitas daya seperti ketidak seimbangan, harmonisa dan fliker. Untuk fluktuasi tegangan pada sistem microgrid disebabkan oleh variasi daya aktif dan reaktif yang dihasilkan oleh pembangkit tersebar dan ini dapat memperngaruhi stabilitas dan keandalan jaringan [3], [4]. Sedangkan harmonisa yang dihasilkan disebabkan oleh konverter pada pembangkit tersebar dan beban nonlinier dapat mempengaruhi impedansi sistem dan menimbulkan distorsi 
tegangan [5]. Kualitas daya listrik pada sistem microgrid memiliki peranan penting dalam menjaga kualitas dan keandalan sistem tenaga.

Paper ini akan membahas studi terkait potensi fenomena harmonisa yang dihasilkan oleh sistem microgrid yang berdampak pada sistem AC dan solusi dalam mengeliminasi harmonisa.

\section{SISTEM MICOGRID}

\section{A. Model Sel Surya}

Blok PV Array mengimplementasikan serangkaian modul fotovoltaik. Array dibangun dari string modul yang dihubungkan secara paralel, setiap string terdiri dari modul yang dihubungkan secara seri. Blok ini memungkinkan untuk membuat model modul PV [6].

Blok Array PV adalah model lima parameter yang menggunakan sumber arus $I_{L}$ (arus yang dibangkitkan cahaya), dioda (parameter I0 dan $\mathrm{nI}$ ), resistansi seri Rs, dan resistansi shunt Rsh untuk mewakili karakteristik V-I yang bergantung pada radiasi dan suhu dari modul.

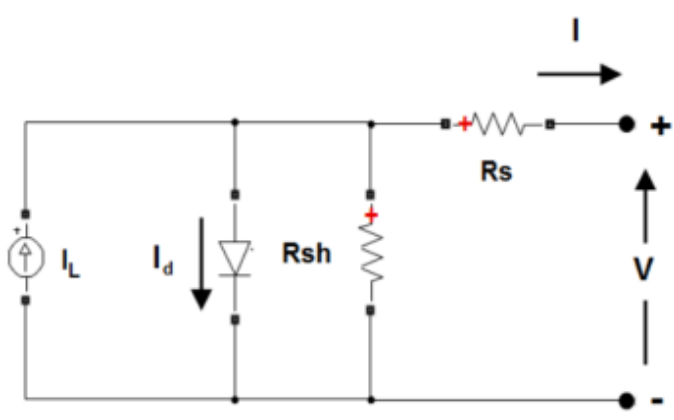

Gbr 1. Rangkaian ekivalen sel surya.

Karakteristik V-I diode untuk modul PV dapat dituliskan dengan persamaan berikut:

$$
\begin{aligned}
& I_{d}=I_{0}\left[\exp \left(\frac{V_{d}}{V_{T}}\right)-1\right] \\
& V_{T}=\frac{k T}{q} \times n I \times N \text { cell }
\end{aligned}
$$

dimana :

$I_{d} \quad$ : arus diode (A)

$V_{d} \quad$ : tegangan diode $(\mathrm{V})$

$I_{0} \quad$ : arus saturasi diode (A)

$n I \quad$ : factor ideal diode $k \quad$ : konstanta boltzman $1,2806 \times 10^{-23} \mathrm{~J} / \mathrm{K}$

$q$ : muatan electron $1,6022 \times 10^{-19} \mathrm{C}$

$T \quad$ : suhu sel (K)

Ncell : jumlah sel yang tehubung seri pada modul

\section{B. Model Turbin Angin}

Daya mekanis yang dihasilkan turbin angin dapat ditulis:

$P_{t}=0,5 \rho \pi R^{2} C_{p} \lambda v_{w}^{3}$

dimana :

$\rho \quad:$ densitas udara $\mathrm{kg} / \mathrm{m}^{3}$

$\mathrm{R} \quad$ : radius dari blade turbin

$v_{W} \quad:$ kecepatan angin $(\mathrm{m} / \mathrm{s})$

Dan $C_{p} \lambda$ adalah koefisien daya yang

merupakan fungsi dari rasio tip-speed $\lambda$. Tipspeed rasio merupakan:

$$
\lambda=\frac{\omega_{r} R}{v_{w}}
$$

dimana $\omega_{r}$ adalah kecepatan generator.

\section{HASIL DAN PEMBAHASAN}

\section{A. Voltage Source Converter (VSC)}

Konverter thyristor sebagai sumber arus pada sistem AC. Untuk konverter 6 pulsa dengan transformator terhubung $\mathrm{Y}-\mathrm{Y}$ dengan persamaan fourier [7]:

$I_{g}=2 \frac{\sqrt{3}}{\pi} I_{d c}\left[\sin \omega t+\frac{1}{5} \sin 5 \omega t+\frac{1}{7} \sin 7 \omega t-\frac{1}{11} \sin 11 \omega t+\frac{1}{13} \sin 13 \omega t+\cdots\right]$

Sedangkan persamaan dengan transformator terhubung Y- $\Delta$ adalah:

$I_{g}=2 \frac{\sqrt{3}}{\pi} I_{d c}\left[\sin \omega t+\frac{1}{5} \sin 5 \omega t+\frac{1}{7} \sin 7 \omega t-\frac{1}{11} \sin 11 \omega t+\frac{1}{13} \sin 13 \omega t+\cdots\right](6)$

Sistem pada menggunakan 12 pulsa yang terdiri dari converter $\mathrm{Y}-\mathrm{Y}$ dan $\mathrm{Y}-\Delta$. Arus pada konverter 12 pulsa merupakan pejumlahan dari persamaan 1 dan 2 .

$I_{g}=4 \frac{\sqrt{3}}{\pi} I_{d c}\left[\sin \omega t-\frac{1}{11} \sin 11 \omega t+\frac{1}{13} \sin 13 \omega t-\frac{1}{23} \sin 23 \omega t+\frac{1}{25} \sin 25 \omega t+\cdots\right]$

Sehingga sistem 12 pulsa mempunyai harmonisa pada urutan ke-11, ke-13 dan pada 
urutan harmonisa $12 k \pm 1$. Atau persamaan dapat disederhanakan menjadi:

$$
\begin{aligned}
I_{g} & =2 \frac{\sqrt{3}}{\pi} I_{d c} \sum_{n=1}^{\infty} \frac{1}{n} \sin (n \omega t) \\
n & =12 k \pm 1, k=1,2,3, \cdots
\end{aligned}
$$

\section{B. Filter Harmonisa}

Filter harmonisa tiga fasa merupakan komponen yang terhubung parallel yang digunakan pada sistem tenaga untuk mengeliminasi distorsi harmonisa dan untuk koreksi faktor daya. Komponen nonlinier konverter elektronika daya menghasilkan arus harmonisa atau tegangan harmonisa yang diinjeksikan ke sistem.

Hasil dari arus yang terdistorsi mengalir melalui impedansi sistem dan menghasilkan distorsi tegangan. Filter harmonisa mengurangi distorsi dengan mengalihkan arus harmonisa pada impedansi yang rendah. Filter harmonisa didesain dengan karakteristik kapasitif pada frekuensi dasar, sehingga dapat digunakan untuk menghasilkan daya reaktif yang diperlukan dan perbaikan faktor daya.

Untuk dapat mencapai distorsi yang diinginkan, beberapa rangkaian filter dari berbagai jenis biasanya terhubung secara parallel. Jenis rangkaian filter yang umum digunakan adalah [8]:

1.Band-pass filters, digunakan untuk filter harmonisa dengan orde rendah antara lain 5th, 7th, 11th, $13^{\text {th }}$, dll. Band-pass filter dapat dituning pada satu frekuensi (single tuned filter) atau dua frekuensi (Doubletuned filter)

2.High-pass filter, digunakan untuk memfilter harmonisa dengan orde tinggi dan mampu mengcover rentang frekuensi yang luas. Salah satu jenis high-pass filter yaitu C-type high-pass filter digunakan untuk menghasilkan daya reaktif dan resonansi parallel. Rangkaian filter ini digunakan untuk menfilter harmonisa dengan orde rendah contoh harmonisa orde 3 , serta tetap menjaga rugi-rugi nol pada frekuensi dasar.
Rangkaian filter harmonisa tiga fasa dibangun dari komponen RLC. Nilai resistansi, induktansi dan kapasitansi ditentukan dari jenis filter dan dari parameter berikut:

1. Daya reaktif pada nilai nominal tegangan

2. Frekuensi tuning

3. Faktor kualitas (Quality factor). Faktor kualitas diukur dari ketajaman frekuensi tuning. Itu ditentukan oleh nilai resistansi.

Empat jenis filter yang dapat dimodelkan dengan blok filter harmonisa tiga fase ditunjukkan pada gambar 2 .

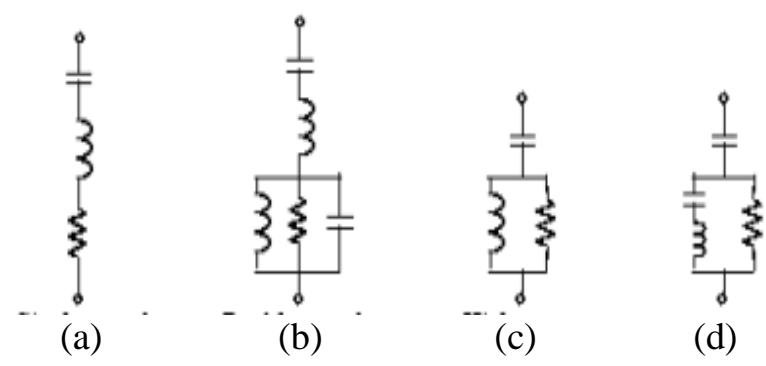

Gbr. 2 Jenis-jenis rangkaian filter, (a) Singletuned, (b) Double-tuned, (c) High-pass, (d) Ctype High-pass

Model sistem yang akan dibangun untuk melihat fenomena distorsi harmonisa dapat dilihat pada gambar 3. Sumber pembangkit tersebar merupakan bagian yang menghasilkan distorsi harmonisa pada sistem.

Sistem yang akan disimulasikan seperti yang terlihat pada gambar 3 dengan sistem DC yang terhubung dengan grid melalui sebuah konverter. Konverter yang digunakan dengan thyristor 12 pulsa untuk mengubah daya DC menjadi AC.

Filter harmonisa terhubung secara parallel antara Bus 1 dan Bus 2 dimana Bus 2 merupakan sumber harmonisa yang semestinya mengalir pada filter harmonisa dan tidak mengalir pada Bus 1 yang merupakan sistem AC yang terdistorsi harmonisa. 


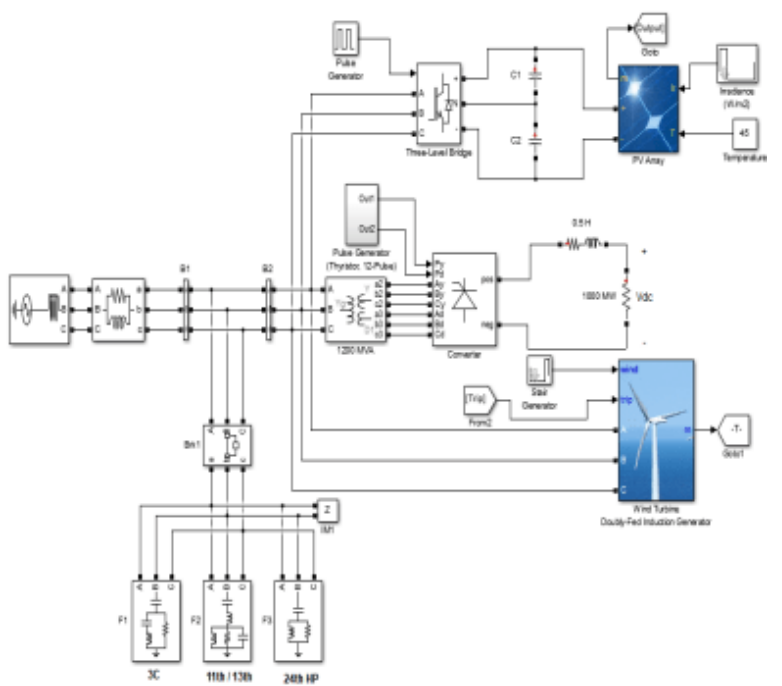

Gbr. 3 Model sistem

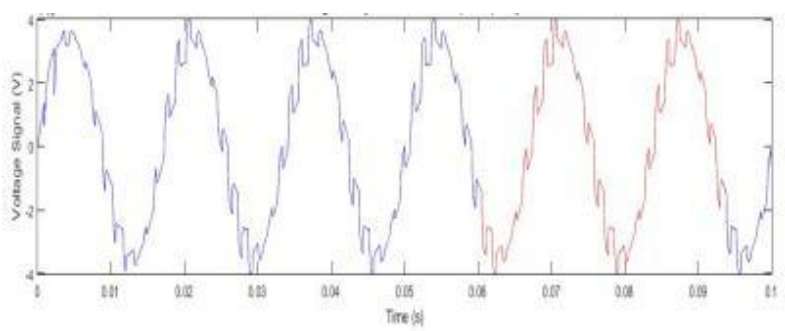

(a)

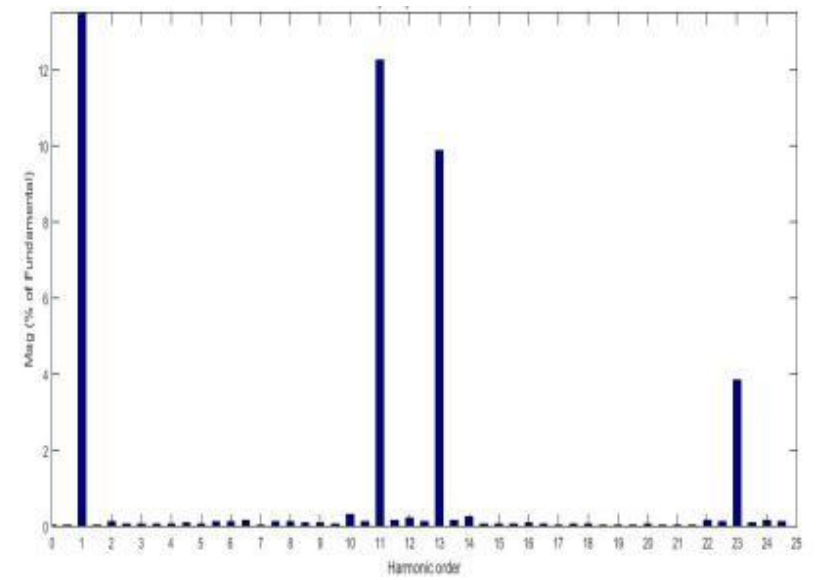

(b)

Gbr. 4 (a) Gelombang sinusoidal teganga yang terdistorsi harmonisa pada Bus 1, (b) Spektrum harmonisa sebelum dipasang filter harmonisa dengan $\mathrm{THD}_{\mathrm{v}} 17,03 \%$

Dari gambar 4 dapat dilihat kondisi awal gelombang sinusoidal tegangan pada bus 1 terdistorsi dengan gelombang harmonisa. Dengan menggunakan fast fourier transform (FFT) dengan mengambil sampel 2 siklus sinusoidal diperoleh magnitud dan urutan frekuensi harmonisa masing-masing gelombang. Harmonisa yang terdapat pada gelombang sinusoidal pada Bus 1 antara lain urutan ke-11, ke-13 dan ke-23. Total distorsi harmonisa tegangan $\left(\mathrm{THD}_{\mathrm{V}}\right)$ adalah $17,03 \%$.

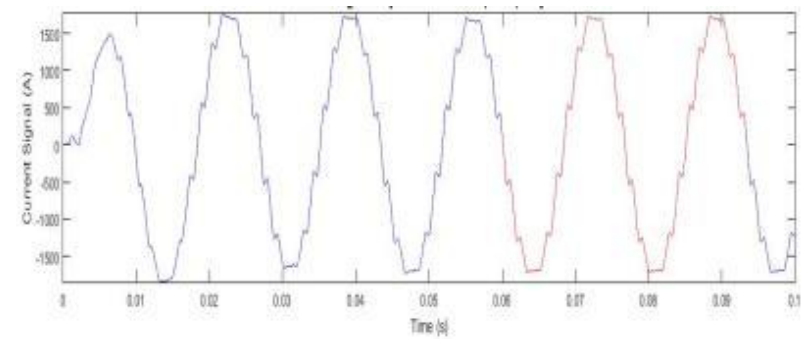

(a)

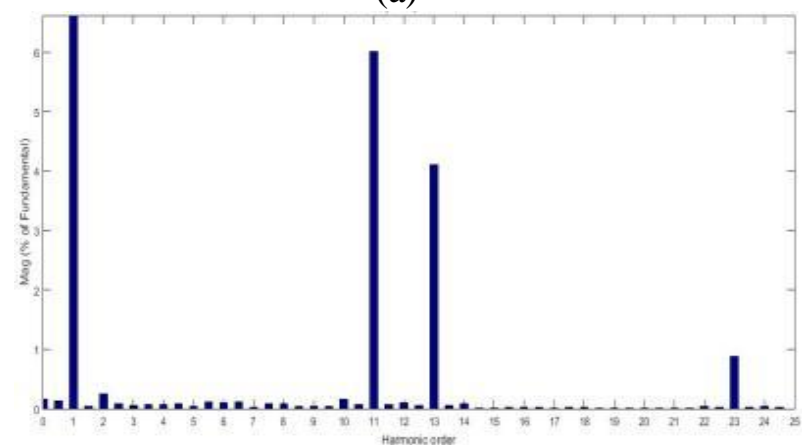

(b)

Gbr. 5 (a) Gelombang sinusoidal arus yang teristorsi harmonisa pada Bus 1 (b) Spektrum harmonisa sebelum dipasang filter harmonisa $\mathrm{THD}_{\mathrm{I}} 7,40 \%$.

Dari gambar 5 dapat dilhat untuk gelombang sinusoidal arus terdapat distorsi harmonisa yang sama yaitu pada urutan ke11, ke-13 dan ke-23. Distorsi harmonisa arus lebih kecil dari pada distorsi harmonisa yang dihasilkan pada tegangan. Pada Bus 2 yang terhubung dengan sistem pemabangkit tersebar (Distributed Generation) yang menjadi sumber harmonisa pada sistem. Terdapat beberapa urutan harmonisa yang dihasilkan, yang terbesar dihasilkan pada harmonisa urutan ke-11, ke-13 dan urutan ke23 sedangkan urutan harmonisa yang lain memiliki magnitude yang kecil. Total distorsi harmonisa (THD) pada bus 2 adalah 7,4\% seperti pada gambar 6b.

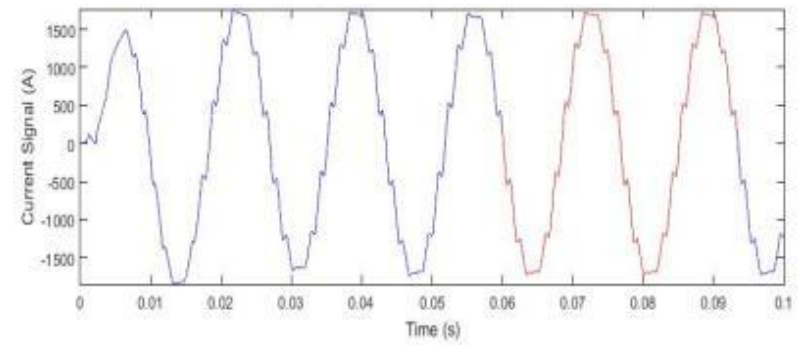

(a) 


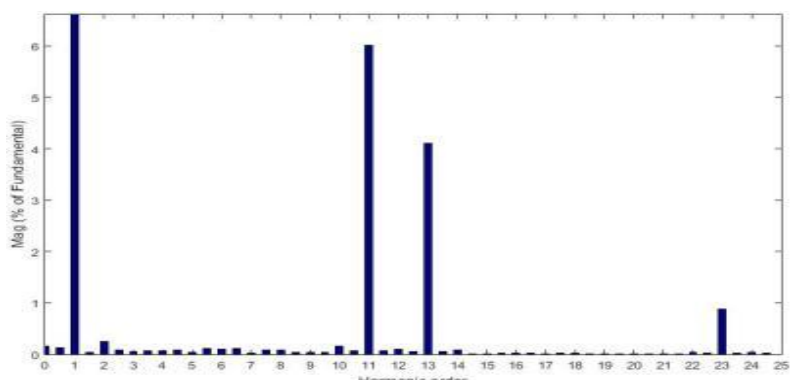

(b)

Gbr. 6 (a) Gelombang sinusoidal arus yang terdistorsi harmonisa pada Bus 2 (b) Spektrum harmonisa sebelum dipasang filter harmonisa dengan THD $_{\text {I }} 7,40 \%$

Pada gambar 7 merupakan high-pass filter yang mempunyai karakteristik jangkauan tuning frekuensi yang lebar dengan impedansi terendah pada frekuensi $1500 \mathrm{~Hz}$ yaitu $11,32 \Omega$. Filter ini diharapkan mampu menarik distorsi harmonisa urutan ke-23 dengan nilai frekuensi $1380 \mathrm{~Hz}$.

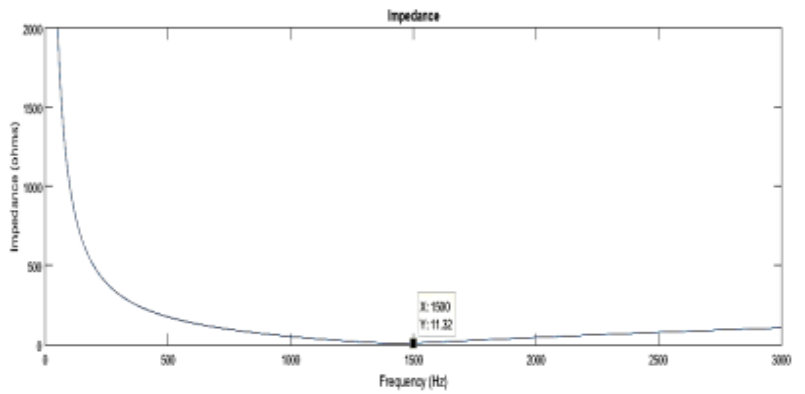

(a)

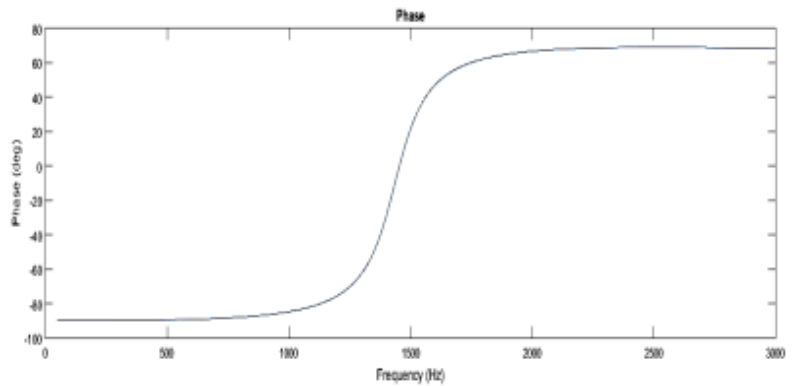

(b)

Gbr. 7 (a) Frekuensi tuning high-pass filter dengan cakupan frekuensi yang luas yang didesain untuk menfilter harmonisa urutan 23, (b) Phasor terhadap frekuensi dari high-pass filter

Pada gambar 8 merupakan kurva karakteristik dari double-tuned filter yang mempunyai tuning pada 2 nilai frekuensi. Rangkaian filter ini didesain untuk menfilter harmonisa pada urutan ke-11 dan ke-13 dengan frekuensi $660 \mathrm{~Hz}$ dan $780 \mathrm{~Hz}$. Nilai impedansi filter pada frekuensi $660 \mathrm{~Hz}$ adalah 7,484 ohm dan nilai impedansi filter pada frekuensi $780 \mathrm{~Hz}$ adalah 5,672 ohm. Dengan impedansi terkecil pada masingmasing frekuensi tersebut akan menarik arus harmonisa pada urutan ke-11 dan ke-13 sehingga harmonisa tidak mengalir ke sistem.

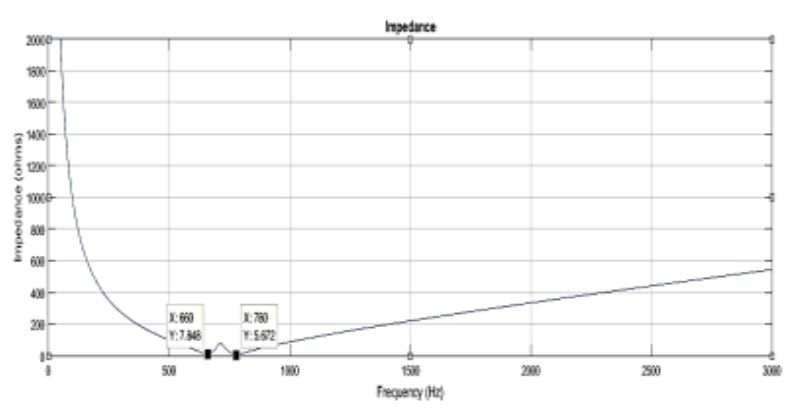

(a)

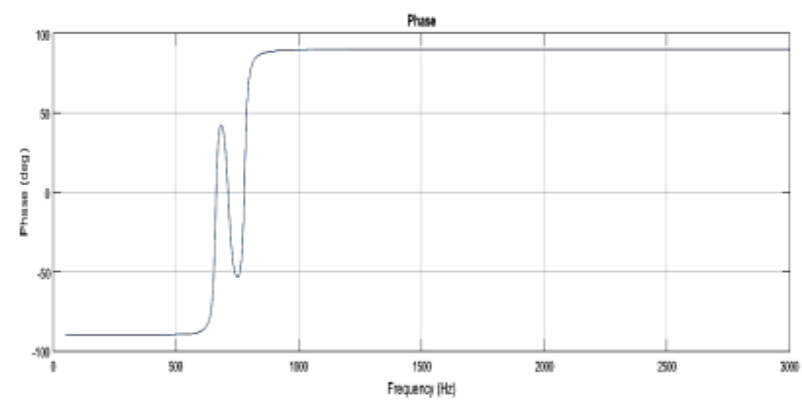

(b)

Gbr. 8 (a) Frekuensi tuning double-tuned filter dengan dua frekuensi tuning $660 \mathrm{~Hz}$ dan $780 \mathrm{~Hz}$, (b) Phasor terhadap frekuensi dari double-tuned

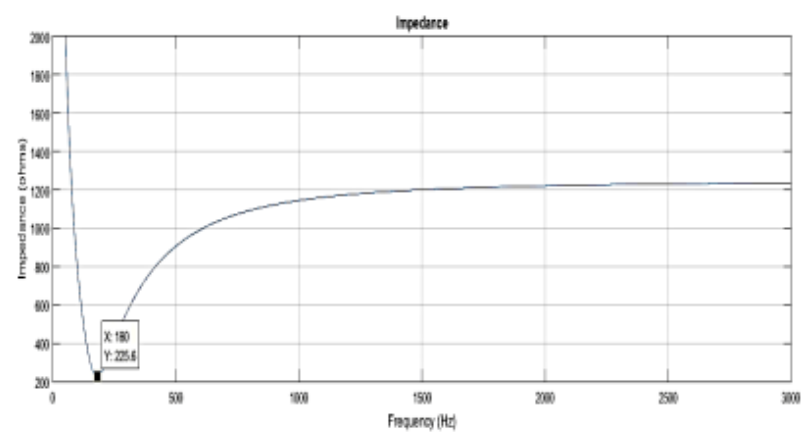

(a)

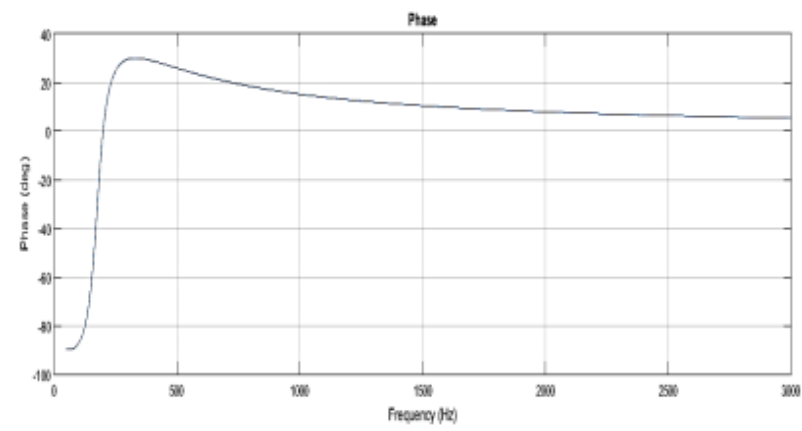

(b)

Gbr. 9 Frekuensi tuning C-type High-pass filter dengan karakteristik ketajaman tuning pasa frekuensi $180 \mathrm{~Hz}$ 
C-type High-pass filter didesain untuk menfilter harmonisa urutan ke-3 dengan frekuensi tuning $180 \mathrm{~Hz}$ dengan impedansi pada frekuensi tersebut adalah 225,6 ohm seperti pada gambar 9 .
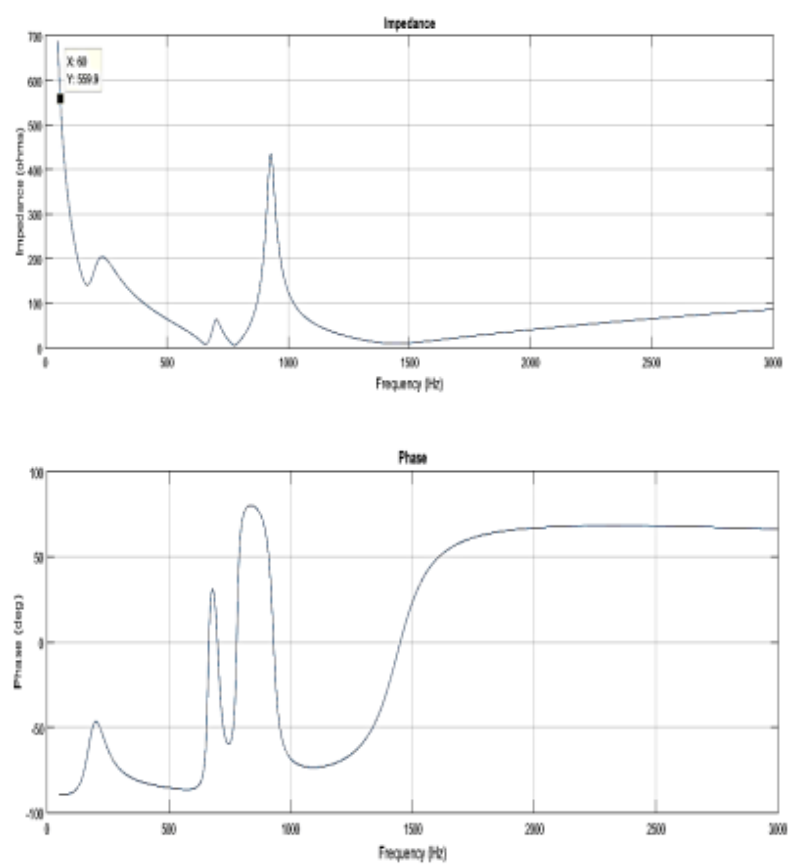

Gbr.10 Karakteristik impedansi terhadap frekuensi dari keseluruhan filter yang terpasang dengan impedansi 559,9 ohm pada frekuensi dasar $60 \mathrm{~Hz}$

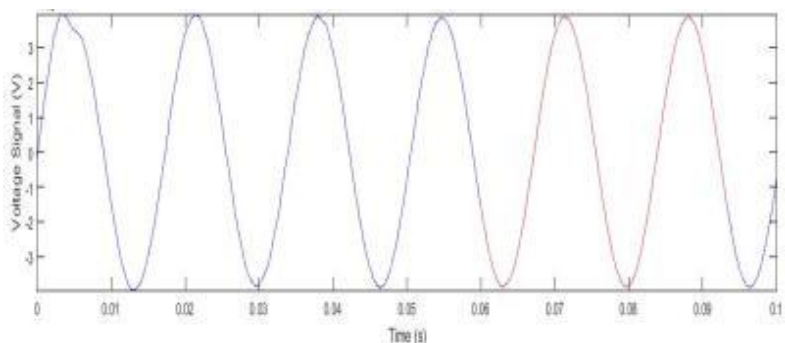

(a)

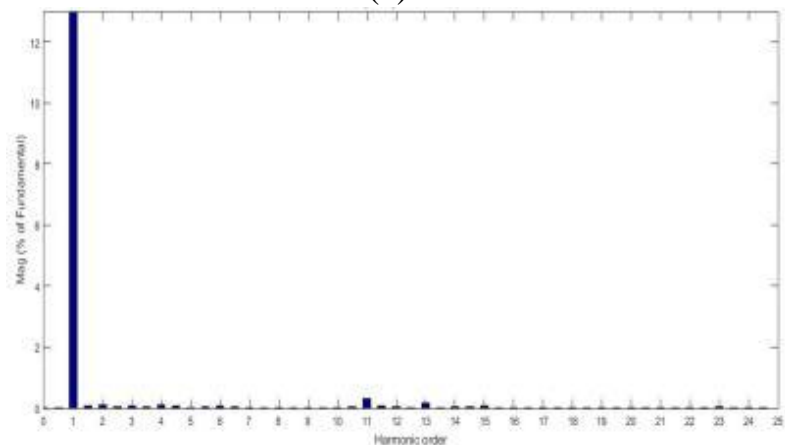

(b)

Gbr. 11 (a) Gelombang sinusoidal tegangan pada Bus 1, (b) Spektrum harmonisa tegangan sistem pada bus 1 setelah dipasang filter harmonisa $0,69 \%$
Pada gambar 11a dapat dilihat bahwa gelombang sinusoidal dari tegangan pada Bus 1 tidak terdistorsi harmonisa dan dari spektrum harmonisa pada gambar 11b dapat dilihat urutan harmonisa ke-11, ke-13 dan ke23 sudah tereliminasi dengan total distorsi harmonisa tegangan (THDV) setelah difilter yaitu $0,69 \%$. Filter harmonisa yang sudah didesain telah efektif menyerap distorsi harmonisa berdasarkan frekuensi tuning masing-masing agar tidak mengalir ke sistem.

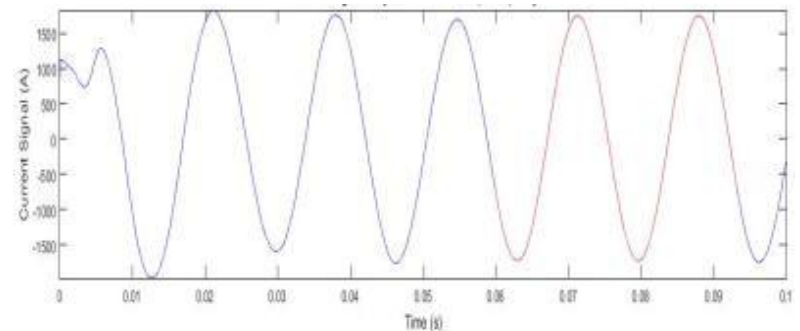

(a)

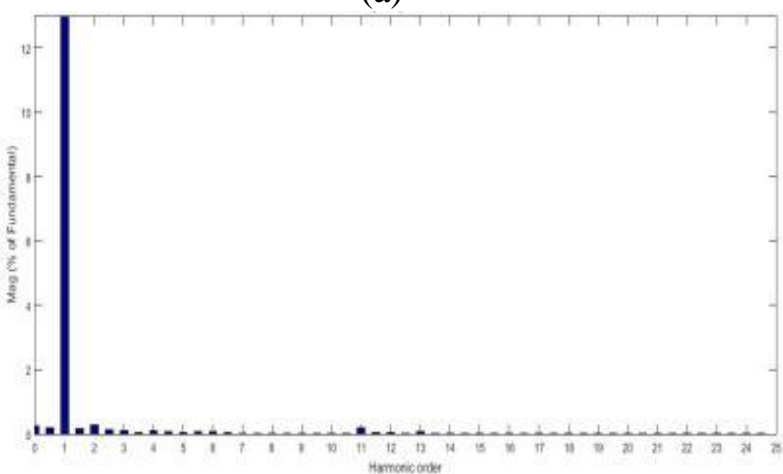

(b)

Gbr. 12 (a) Gelombang sinusoidal arus pada Bus 1, (b) Spektrum harmonisa setelah dipasang filter harmonisa $0,48 \%$

Pada gambar 12.a dapat dilihat gelombang sinusoidal arus pada Bus 1 sudah tidak terdistorsi gelombang harmonisa, dari spektrum harmonisa pada gambar $12 \mathrm{~b}$ dapat dilihat tidak ada magnitud harmonisa urutan ke-11, ke-13 dan ke-23 telah tereliminasi dengan total distorsi harmonisa arus $\left(\mathrm{THD}_{\mathrm{I}}\right)$ adalah $0,48 \%$.

\section{KESIMPULAN}

Sistem microgrid yang terdiri dari pembangkit terbarukan berskala kecil dalam kondisi terhubung dengan sistem dapat menimbulkan distorsi harmonisa pada sistem, urutan harmonisa yang ditimbulkan bergantung pada kelipatan besaran pulsa pada gate voltage source converter, model 
yang dibangun meggunakan 12 pulsa sehingga menimbulkan harmonisa dengan persamaan $n=12 k \pm 1$, . Desain filter dengan frekuensi tuning telah mampu mengeliminasi harmonisa pada sistem.

\section{UCAPAN TERIMA KASIH}

Penelitian mendapatkan dukungan dana dari DIPA Fakultas Teknik Universitas Lampung.

\section{REFERENSI}

[1] J. M. Guerrero, J. Matas and L. G. de Vicuna, M. Castilla and J. Miret, "Decentralized control parallel operation of distributed generation inverting using resisteive output impedance", IEEE Trans. On Industrial Electronics, vol. 54, no. 2, pp. 994-1004, 2007.

[2] A. Singh, R. S. Bhatia, S. Chanana, An Anti-Islanding Technique for Grid-
Connected DG and multi DG System, IEEE, 2018.

[3] J. Arrilaga, D. A. Bradley, and P. S. Bodger, Power System Harmonics, John Wiley \& Sons, New York, 1985.

[4] G.W. Chang and A. Testa, "Harmonics and Interharmonics Theory," IEEE Tutorial Course on Harmonics Modeling and Simulation, Course Text 07TP184, June 2007, IEEE.

[5] R. C. Dugan, M. F. McGranaghan, S. Santoso, and H. W. Beaty, Electrical Power System Quality, McGraw Hill, 2012.

[6] National Renewable Energy Laboratory, System Advisor Model, http://sam.nrel.gov, 2014

[7] Kim, C. K., Sood, V. K., Jang, G. S., Lim, S. J., \& Lee, S. J. HVDC Transmission: Power Conversion Applications in Power Systems. John Wiley and Sons. 2010.

[8] M. H. Rashid. Power Electronics Handbook Devices, Circuits, and Applications. Elsevier 2011. 